VI. Descriptions of new genera and species of Halticinæ. By Joseph S. BALY, F.L.S.

[Read 7th June, 1876.]

\title{
List of SPECIES.
}

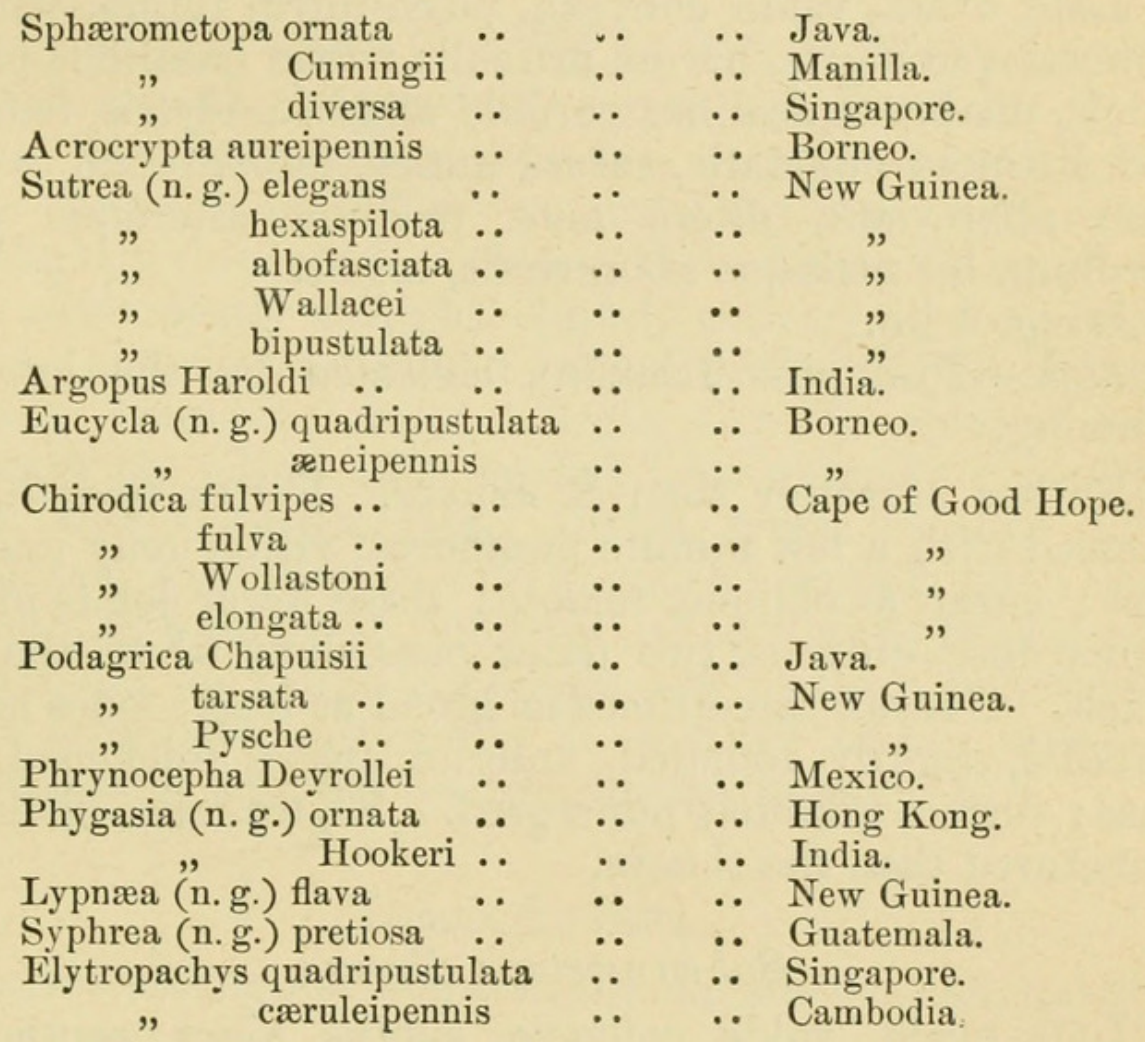

\section{Genus Sphærometopa, Chapuis. \\ Gen. Col. xi. p. 80. \\ Spharometopa ornata.}

Rotundato-ovata, valde convexa, rufo-fulva, nitida, antennarum articulis $2-10$ elytrisque nigris, his distincte punctatis, margine inflexo apiceque rufo-fulvis, utrisque fasciis duabus utrinque abbreviatis, unâ ante, alterâ pone medium positis, flavis.

Long. 3 lin.

Hab.-Java.

Head finely punctured, carina obsolete, encarpæ not contiguous. Thorax nearly three times as broad as long;

TRANS. FNT. SOC. 1876.-PART III. (OCT.) 
sides nearly straight, slightly converging from base to apex; anterior angles thickened, obtusely truncate; disk finely but not very closely punctured. Scutellum trigonate, its apex acute. Elytra rather coarsely punctured, shining black; the apex and the inflexed limb rufo-fulvous; each elytron with two slightly irregular transverse bands, abbreviated on the outer margin and at the suture, flavous.

\section{Sphærometopa Cumingii.}

Late ovata, valde convexa, piceo-fulva, nitida, scutello antennisque nigris, harum articulis tribus basalibus piceofulvis, duabus apicalibus sordide albidis; elytris tenuiter sed distincte punctatis, suturâ antice, fasciâ basali extrorsum abbreviatâ, alterâ ante medium alterâque pone medium, his utrinque abbreviatis, nigris.

Long. 4 lin.

Hab.-Phillipine Islands; collected by the late $\mathrm{H}$. Cuming.

Rather narrower than S. ornata. Vertex smooth, impressed with a few minute punctures, visible only under a lens; encarpæ oblique, remote; three lower joints of antennæ fusco-fulvous, two outer ones dirty white, the rest black. Thorax three times as broad as long; sides nearly parallel, slightly rounded, anterior angles thickened, obtuse; surface minutely punctured. Elytra more distinctly punctured than the thorax.

\section{Sphrorometopa diversa.}

Late ovata, valde convexa, subtus nigra, prothorace piceo, supra castaneo; antennis nigris, articulis duobus apicalibus albidis.

Long. $3 \frac{2}{3}$ lin.

Hab.-Singapore; collected by $\mathrm{Mr}$. Wallace.

Head remotely punctured; encarpæ quadrangular, not contiguous; basal joint of antennæ equal in length to the two following united ; three lower joints nigro-piceous, two outer ones dirty white. Thorax three times as broad as long; sides rounded, scarcely converging in front; hinder angles distinct, the apex acute; anterior angles thickened, obtusely truncate; disk distinctly but not very closely punctured, the lateral and the outer third of the basal margins narrowly edged with nigro-piceous. Elytra broader than the thorax, their surfaces rather more strongly punctured than that of the latter. 
Genus Acrocrypta, Baly.

Journ. of Entom. i. p. 457.

Acrocrypta aureipennis.

Rotundata, convexa, rufa, nitida, scutello purpureonigro; antennis extrorsum modice incrassatis, articulis 7 10 nigris, ultimo albo; elytris aureis, late viridi-limbatis.

Var. A. Pectore abdomineque piceo-tinctis.

Long. $3 \frac{1}{2}-4$ lin.

Borneo (Sarawak); collected by Mr. Wallace.

Head smooth, impunctate, impressed down the front with a faint longitudinal groove; encarpæ remote; antennæ shorter than half the length of the body, their outer half slightly thickened. Thorax three times as broad as long; sides nearly straight, slightly converging from base to apex, anterior and hinder angles thickened, the former obtusely truncate; basal margin slightly oblique and bisinuate on either side, medial lobe obtusely rounded; upper surface impunctate. Elytra much broader than the thorax, shoulders broadly rounded; surface finely and subremotely punctured; humeral callus slightly thickened; just without the callus is a single row of deep punctures, which terminate posteriorily in a large fovea; inflexed limb concave, its outer margin dilated, metallic blue.

\section{Génus Sutrea.}

Corpus oblongo-elongatum, aut anguste ovatum, modice convexum.

Caput exsertum, breve, facie perpendiculari, inter oculos elevatâ, encarpis contiguis; antennis filiformibus. Thorax transversus, lateribus marginatis. Elytra thorace paullo latiora, parallela aut anguste ovata, confuse punctata, limbo laterali distincte dilatato, paullo reflexo. Pedes: coxis anticis prosterno paullo altioribus; femoribus posticis incrassatis; tibiis dorso non sulcatis, quatuor anterioribus apice muticis, posticis spino acuto armatis; tarso postico ad apicem tibiæ inserto; unguiculis appendiculatis. Prosternum oblongum, concavum, apice plerumque dilatatum; acetabulis anticis apertis ; mesosternum trigonatum, apice angulato-emarginatum.

Nearly allied to Sebcthe, separated by its narrower form, the less dilated sides of the thorax and of the elytra, 
and by the absence of the longitudinal sulcation on the dorsal surface of the tibiæ; from Aphthona* it is separated by the unarmed apices of the four anterior tibiæ.

\section{Sutrea elegans.}

Flava, nitida, oculis, femorum posticorum apice elytrisque nigris, his tenuissime, confuse punctulatis, utrisque apice maculisque duabus magnis flavis.

Fæm.-Abdominis segmento ultimo apice obtuse rotundato.

Long. $3 \frac{1}{2}-4$ lin.

Hab.-New Guinea; collected by Mr. Wallace.

Head shining, impunctate, face elevated between the eyes, the elevated portion forming a broad ill-defined carina, the apex of which is angulate; encarpæ subtrigonate, contiguous; antennæ rather more than half the length of the body, slender, filiform, 3rd joint much longer than the $2 \mathrm{nd}$, outer joints stained with fuscous. Thorax more than three times as broad as long; sides rounded, slightly sinuate just behind the anterior angle, the latter very obtusely rounded, hinder angles armed with a small lateral tooth; surface smooth, very minutely and subremotely punctured, lateral border reflexed. Scutellum rufo-piceous, semi-rotundate. Elytra very finely punctured, black or pitchy-black, each with the apical border, together with two large irregular transverse patches, yellow. These patches, which are abbreviated externally at a distance from the lateral border, extend inwardly nearly to the suture; they are placed one before the middle and the other between the middle and the apex.

\section{Sutrea hexaspilota.}

Anguste ovata, convexa, piceo-fulvo, nitida, femoribus posticis piceis; thorace flavo-albo, impunctato; capite (antennis exceptis) elytrisque nigris, his tenuiter punctulatis, utrisque maculis tribus, duabus subrotundatis vix ante medium transversim positis, unâque transversâ, sublunatâ, ante apicem positâ, flavo-albis.

* Dr. Chapuis errs in stating that the four anterior tibiæ in Aphthona are without apical spines; they are present in all the species that I have examined, but are frequently hidden by stiff hairs, and therefore difficult to discover without a good lens. 
Mas.-Abdominis segmento ultimo trilobato, lobis fere æquilongis, lobo intermedio concavo, sursum paullo reflexo, apice obtuso, lobis lateralibus latis, obtuse truncatis.

Fæm.-Abdominis segmento ultimo apice bilobato.

Long. $2 \frac{1}{2}$ lin.

Hab.-New Guinea (Dorey).

Head smooth, impunctate, front impressed on either side, just within the inner margin of the eye, with a deep fovea ; carina well defined, narrowed at base and apex; encarpæ subpyriform; space between the antennæ, lower half of clypeus and mouth piceous. Thorax more than twice as broad as long; sides rounded, anterior angles thickened, obtusely rounded, produced laterally into a short acute tooth. Elytra finely but not very closely punctured.

\section{Sutrea albofasciata.}

Anguste ovata, convexa, nitida, scutello capiteque nigris, antennis basi sordide fulvis; thorace impunctato, flavo-albo; elytris distincte punctulatis, nigris, utrisque fasciâ vix ante medium, alterâ apicem versus, utrinque abbreviatâ, maculâque apicali flavo-albis; pectore abdomineque pallide piceis; pedibus (femoribus posticis nigris exceptis) sordide fulvis.

Var. A. Elytrorum maculâ apicali obsoletâ.

Mas.-Abdominis segmento ultimo apice trilobato, lobis æquilongis; lobo medio concavo, vix sursum reflexo, apice obtuse rotundato.

Fæem.-Abdominis segmento ultimo apice integro, rotundato.

Long. $2-21$ lin.

Hab.-New Guinea (Dorey).

Head smooth and shining, impunctate; antennæ with the four lower joints obscure fulvous, the 5th, together with the apices of the 3rd and 4th, piceous, six outer joints black ; 3rd joint twice the length of the 2 nd; encarpæ subpyriform, contiguous; carina ill-defined at its upper half, its apex acute, lower end contracted, and produced for a short distance down the clypeus; apex of the latter, together with the labrum, piceous. Thorax more than twice as broad again as long; sides rounded, anterior angles thickened, obtusely truncate, hinder angles armed with a small lateral tubercle. Scutellum trigonate. Elytra ovate, distinctly punctured. 


\section{Sutrea Wallacei.}

Anguste ovata, convexa, sordide flava, nitida, antennis extrorsum nigris; scutello rufo-piceo; elytris distincte punctulatis, nigris, utrisque fasciis dnabus, utrinque abbreviatis, unâ vix ante medium, alterâ ante apicem, flavoalbis; corpore subtus piceo tincto.

Mas.-Abdominis segmento ultimo longitudinaliter sulcato; apice trilobato, lobo medio sursum reflexo, apice obtuso, lobis lateralibus vix brevioribus, latis, obtuse rotundatis.

$$
\begin{aligned}
& \text { Long. } 12 \frac{2}{3}-2 \text { lin. } \\
& \text { Hab.-New Guinea (Dorey). }
\end{aligned}
$$

Similar in sculpturing, in form of carina, \&c., to the last species ( $S$. albofasciata). Antennæ fulvo-piceous, the three outer ones black. Thorax with the anterior angles thickened, obtuse, faintly produced laterally; sides very regularly rounded. Elytra ovate, more finely punctured than S. albofasciata.

\section{Sutrea bipustulata.}

Anguste ovata, convexa, flavo-alba, nitida, antennis extrorsum, pectore, abdomine pedibusque posticis piceis; scutello elytrisque nigris, his distincte punctulatis, utrisque pustulâ transversâ, fere prope medium positâ, flavo-albo ornatis.

Var. A. Elytrorum pustulis suturâ confluentibus, fasciam transversam extrorsum abbreviatam formantibus.

Mas.-Abdominis segmento ultimo apice trilobato, lobo medio lato, brevi, apice truncato.

From.-Abdominis segmento ultimo apice truncato, bisinuato.

Long. $2-2 \frac{1}{2}$ lin.

Hab.-New Guinea (Dorey).

Clypeus transversely concave, its upper portion thickened; carina broad and ill-defined below, narrowed and acuminate above. Thorax rather more than twice as broad as long; sides nearly parallel at the base, rounded and converging anteriorly, anterior angles thickened, obtuse; surface impunctate. Hinder tibiæ and tarsi rufopiceous. Prosternum narrowed between the coxæ, triangularly dilated posteriorly, its apex truncate. 


\section{Genus Argopus, Fischer.}

The insect described below differs from the hitherto described species of the genus in having the anterior margin of the clypeus entire, and not emarginate; it agrees, however, so completely in all other characters, including the spine at the apices of all the tibiæ, that I have not hesitated in placing it in the genus.

\section{Argopus Haroldi.}

Subhemisphæricus, rufo-fulvus, nitidus, oculis nigris, metasterno abdominisque basi piceis; elytris profunde punctatis, cæruleo-nigris, anguste rufo-limbatis, utrisque maculis sex 1-2-2-1 dispositis flavis ornatis.

Long. $2 \frac{1}{3}$ lin.

Hab.-India.

Head short, trigonate; clypeus deflexed, its anterior margin entire; carina broad, ovate, its medial line occupied by a short longitudinal ridge; encarpæ remote, well defined, subquadrate. Thorax twice as broad as long; basal margin bisinuate on either side; medial lobe slightly produced, obtuse; sides distinctly margined, rounded from base to apex, anterior angles subacute; upper surface smooth and shining, remotely impressed with coarse, deep punctures. Scutellum small, trigonate. Elytra coarsely and deeply punctured, bluish-black, each very narrowly edged with rufous, and having on the disk six subrotundate, flavous spots,-one at the base, two placed transversely before the middle, two transversely behind the latter and one subapical. Legs short, robust, all the thighs thickened, the hinder pair scarcely thicker than the others; tibix curved outwardly, and thickened at the apex; two hinder pairs with the outer edge deeply grooved on the lower two-thirds; edges of the groove produced on either side at the lower end into a flattened tooth; apices of all the tibiæ armed with a small moveable spine; those on the hinder pair not larger than the others; basal joint of tarsus dilated.

\section{Genus Eucycla.}

Corpus rotundatum, valde convexum. Caput in thoracem fere totum immersum, trigonatum ; facie perpendiculari, inter antennas elevatâ ; clypeo cuneiformi, postice elevato, carinâ obsoletâ; encarpis transversis, contiguis; 
antennis filiformibus, corpore longioribus $\delta$, illo brevioribus + , basi fere approximatis, articulo primo elongato, paullo incrassato, articulo ultimo compresso, elongatoovato; oculis magnis, integris, oblongis. Thorax transversus, basi utrinque bisinuatus, lobo medio distincte producto, rotundato. Scutellum subtrigonatum. Elytra thorace latiora, late rotundata, distincte marginata, punctato-striata, limbo inflexo plano. Pedes robusti; femoribus posticis valde incrassatis; tibiis dorso planis, ad apicem vix concavis, quatuor anticis muticis; tarso postico ad tibiæ apicem inserto; unguiculis appendiculatis. Prosternum transversum, coxis anticis fere æquialtum; acetabulis anticis apertis.

\section{Eucycla quadripustulata.}

Rotundata, valde convexa, rufo-picea, nitida, antennis extrorsum, thorace punctato, elytrisque nigris, his subfortiter punctato-striatis, interspatiis irregulariter punctatis; utrisque pustulis duabus magnis, unâ ante, alterâ pone medium positis, rufis.

Long. $1 \frac{3}{4}$ lin.

Hab.-Borneo; Sarawak.

Head nearly impunctate; clypeus wedge-shaped, raised above the general surface of the face, its surface rugulose; five lower joints of antennæ, together with the apex of the penultimate and the whole of the terminal joints, pale piceous, the rest black; basal joint longer than the three following united; jaws nigro-piceous; vertex sometimes rufous. Thorax transversely convex, nearly three times as broad as long; sides rounded and converging from base to apex; anterior angles thickened, broadly obtuse; hinder angles distinct, subacute; surface coarsely punctured. Scutellum small, trigonate. Elytra rather strongly punctate-striate, interspaces irregularly but not very closely punctured; each with two large rufous patches,-one slightly transverse, extending from the basal margin nearly to the middle of the elytron, the other, also transverse, placed halfway between the middle and the apex. Hinder thighs dark piceous; apex of abdomen piceo-fulvous.

\section{Eucycla aneipennis.}

Rotundata, valde convexa, rufo-picea, nitida, capite thoraceque rufis, hoc tenuiter subremote punctato; pedibus antennisque nigris, harum articulis tribus basalibus pallide 
rufo-piceis, articulo ultimo sordide albo ; elytris æneis, sat fortiter punctato-striatis, interspatiis ad latera convexis.

Long. $1 \frac{2}{3}$ lin.

Hab.-Borneo (Sarawak).

Antennæ in the male longer than the body, basal joint more than equal in length to the two following joints united, about equal to the 4 th ; apical joints scarcely compressed, slightly curved; jaws and lower end of clypeus piceous. Thorax nearly three times as broad as long; sides rounded and converging firom base to apex, anterior angles thickened, obtusely and obliquely truncate; surface finely but distinctly punctured. Elytra regularly and rather strongly punctate-striate, interspaces smooth, convex on the outer disk.

\section{Genus Chirodica, Germar.}

Thorax dorso non sulcatus; elytra confuse punctata; femora antica quatuor leviter, postica sat valde incrassata; tibia anticæ quatuor apice muticæ; acetabula antica aperta.

This genus resembles greatly in form many of the European species of Podagrica.

\section{Chirodica fulvipes.}

Anguste oblonga, postice attenuata, convexa, subtus nigra, nitida, pedibus antennisque fulvis, his apice infuscatis; thorace elytrisque metallico-purpureis.

Long. $1 \frac{1}{2}$ lin.

Hab.-Cape of Good Hope.

Head impunctate, faintly strigose; encarpæ trigonate, contiguous at the apex ; carina ill-defined, broad; five lower joints of antennæ fulvous, six outer ones stained with black. Thorax nearly twice as broad as long; sides rounded, slightly converging in front; hinder angles rounded, anterior angles subacute, curved slightly outwards; above convex, impressed in front of the base with a very faint transverse groove, from the middle of which an indistinct longitudinal impressed line which runs upwards halfway across the disk; surface finely but rather closely punctulate. Scutellum trigonate, shining black. Elytra scarcely broader than the thorax at the base, parallel, attenuated towards the apex, the latter in each

TRANS. ENT. SOC. 1876.-PART III. (OCT.) G G 
elytron obliquely truncate; similarly punctured to the thorax.

\section{Chirodica fulva.}

Anguste oblonga, convexa, flavo-fulva, nitida, antennis, basi exceptâ, pallide piceis.

Long. $1 \frac{1}{3}$ lin.

Hab.-Cape of Good Hope.

Head smooth, impunctate; encarpæ obsolete, apex of carina very acute: antennæ robust, nearly equal to the body in length. Thorax convex, one-half broader than long; sides straight and parallel at the base, thence rounded and converging to the apex; angles produced into a subacute tooth, hinder angles distinct; surface finely punctured. Elytra scarcely broader than the thorax, attenuated near the apex, the latter acutely rounded; surface finely punctulate.

\section{Chirodica Wollastoni.}

Elongata, convexa, nigra, nitida, capite, thorace pedibusque fulvis, antennis extrorsum infuscatis.

Long. $1 \frac{1}{2}$ lin.

Hab.-Cape of Good Hope; collected by Mr. Bewick.

Head smooth, impunctate; encarpæ contiguous at the apex; seven or eight outer joints of antennæ stained with fuscous. Thorax more than one-half broader than long; sides nearly straight and parallel at the base; anterior angles thickened, oblique, hinder angles distinct, subacute; upper surface smooth, moderately convex, smooth, impunctate. Elytra rather broader than the thorax; sides parallel, conjointly rounded at the apex; convex, slightly less so along the suture, rather closely impressed with round shallow punctures.

The present and the following species differ from the preceding in being more elongate and less robust and in having all the thighs less thickened.

\section{Chirodica elongata.}

Elongata, parallela, modice convexa, fulvo-picea, nitida, antennis basi, thorace pedibusque fulvis, abdomine elytrisque flavis.

Long. $2 \frac{1}{2}$ lin.

Hab.-Cape of Good Hope.

Head smooth, impunctate; encarpæ transversely trigonate, contiguous; antennæ half the length of the body; 3rd 
to 10th joints short, submoniliform, slightly compressed; three lower joints fulvous, the rest black. Thorax onethird broader than long at the base; sides diverging from the base to beyond the middle, thence obliquely converging and slightly rounded to the apex; hinder angles distinct, anterior slightly produced, thickened, obtusely truncate; surface finely punctured. Elytra broader than the thorax; sides parallel, converging near the apex, each elytron with its apex obtusely rounded; surface flattened along the suture, finely punctulate, minutely granulose-punctate.

\section{Genus Podagrica.}

\section{Podagrica Chapuisii.}

Elongato-ovata, convexa, rufo-fulva, nitida, elytris metallico-violaceis, apice rufis, confuse punctatis; antennis apice nigris.

Long. 2 lin.

Hab.-Java.

Head impunctate; encarpæ trigonate, contiguous ; antennæ robust, four lower joints rufo-fulvous, the following three piceous, the four outer ones black. Thorax half as broad again as long; sides nearly parallel, slightly rounded; hinder angles acute, the anterior obliquely truncate, produced exteriorly into an acute tooth; upper surface finely but distinctly punctured, impressed on either side at the base with a short longitudinal groove. Elytra more strongly punctured than the thorax.

\section{Podagrica tarsata.}

Ovata, convexa, rufo-fulva, nitida, antennis, basi exceptis, tarsis tibiisque posticis apice nigris ; elytris metallico-cæruleis.

Long. $2 \frac{2}{3}$ lin.

Hab.-New Guinea (Dorey).

Labrum and jaws nigro-piceous; carina obsolete; clypeus thickened, distinctly punctured, vertex impunctate; antennæ with the three basal joints rufo-fulvous, the rest black; third joint scarcely longer than the second; eyes black. Thorax nearly twice as broad as long; sides rounded, anterior angles produced into an oblique obtuse tooth; hinder angles tuberculate; disk smooth, impunctate. Scutellum trigonate, its apex obtuse. Elytra finely punctured. 


\section{Podagrica Psyche.}

Late ovata, convexa, rufo-fulva, nitida, antennis extrorsum infuscatis, oculis nigris, elytris cyaneis.

Long. 12 lin.

Hab.- New Guinea.

Head smooth, impunctate; antennæ nearly equal to the body in length; seven outer joints stained with fuscous; third joint nearly twice as long as the second. Thorax one-half broader than long; sides rounded, anterior angles produced into an obtuse tooth; surface smooth, impunctate. Scutellum trigonate, its apex obtuse. Elytra much broader than the thorax, ovate, distinctly punctured.

\section{Genus Phrynocepha, Baly.}

Journ. of Entom. i. 201.

\section{Phrynocepha Deyrollei.}

Elongata, modice convexa, rufa, nitida, antennis, basi exceptis, scutello, pectore, abdomine, tarsisque nigris; elytris subnitidis, metallico-viridibus.

Long. 3 lin.

Hab.-Mexico. A single specimen, formerly in the collection of the late A. Deyrolle.

Head porrect, subquadrate, rugose ; carina linear ; encarpæ raised, smooth, impunctate; vertex nigro-piceous; antennæ moderately robust, attenuated towards the apex, two basal joints, together with the lower two-thirds of the following joints, rufous. Thorax nearly twice as broad as long at the base; sides rounded and diverging at the base, thence obliquely converging to the apex, anterior angles thickened, subacute; surface transversely excavated at the base, broadly excavated in front on either side the medial line, leaving the latter as a raised longitudinal ridge, coarsely but not closely punctured, the interspaces granulose-punctate. Scutellum trigonate, its apex obtuse; the surface smooth, impunctate. Elytra rather broader than the thorax, subparallel, moderately convex, slightly flattened along the suture; the surface closely granulose-punctate, finely but distinctly punctured; on each elytron near the outer margin are two broad, shallow, longitudinal excavations, which run the whole length of the elytron. 


\section{Genus Phygasia, Chevr. MS.}

Corpus anguste ovatum, aut ovatum, convexum.

Caput modice exsertum, facie brevi, perpendiculari; oculis subrotundatis, intus fere rectis; carinâ distinctâ elevatâ; encarpis contiguis; antennis filiformibus, vel ad apicem attenuatis, articulo secundo brevi, tertio illo duplo longiori, quarto æquilongo. Thorax transversus, lateribus rotundatis, reflexo-marginatis, angulis anticis paullo productis, obtusis; disco basi sulco transverso, utrinque abrupte abbreviato, impresso. Elytra thorace latiora, modice convexa, distincte marginata, confuse punctata, infra basin non excavata. Pedes: coxis anticis prosternovix altioribus; femoribus posticis incrassatis; tibiis simplicibus, dorso non canaliculatis, quatuor anticis apice muticis, posticis apice șinâ acutâ armatis; unguiculis appendiculatis. Prosternum inter coxas angustatum, apice incrassatum; acetabulis anticis apertis.

\section{Phygasia ornata.}

Ovata, convexa, rufo-fulva, nitida, abdomine fulvo, antennis (articulo basali piceo excepto), tibiis, tarsis elytrisque nigris, his tenuiter punctulatis, apice rufo-fulvis, utrisque plagâ magnâ prope medium sordide albâ ornatis; scutello rufo-piceo.

Long. $2 \frac{1}{2}-3$ lin.

Hab.-Hongkong ; collected by Mr. Bowring.

Head shining, impunctate; carina narrow, linear, its apex acuminate; antennæ more than half the length of the body, six or seven lower joints thickened, slightly compressed. Thorax more than twice as broad as long; sides rounded, slightly diverging from the base to the middle; anterior angles produced, obtuse; upper surface smooth, impunctate.

\section{Phygasia Hookeri.}

Ovata, convexa, pallide castanea, nitida, antennis, oculis, femorum apice, tibiis tarsisque nigris.

Long. $2 \frac{2}{3}-3$ lin.

Hab.-India (Kaisa Hills); collected by Dr. Hooker.

Head smooth, impunctate; antennæ moderately robust, attenuated towards the apex, six or seven lower joints slightly compressed; eyes black. Thorax twice as broad as long; sides diverging from the base to just beyond the 
middle, thence rounded to the apex; surface smooth, impunctate. Elytra finely but distinctly punctured.

\section{Genus Lypnea.}

Corpus elongatum, convexum. Caput modice exsertum, facie perpendiculari; antennis filiformibus, corporis dimidio longioribus, articulo secundo brevi, tertio illo vix longiori; encarpis transversis, contiguis; carinâ lineariformi. 'Thorax transversus, basi sulco transverso, utrinque abbreviato impressus, angulis anticis paullo productis, obtusis. Elytra thorace paullo latiora, parallela, punctatostriata, limbo laterali distincte dilatato. Pedes simplices; femoribus posticis incrassatis; tibiis anticis quatuor muticis, posticis apice spinâ brevi acutâ armatis; tarsis posticis ad tibiæ apicem insertis; unguiculis appendiculatis. Prosternum coxis æquialtum apice hastato, dorso carinato; acetabulis anticis apertis. Mesosternum trigonatum, antice concavum.

Separated from Lactica and allied genera by the punctate-striate, costate elytra; from Diphanlaca it is distinguished by the form of the thorax, and by the absence of the transverse depression on the elytra.

\section{Lypnea flava.}

Elongata, flava, oculis nigris, elytris regulariter punctato-striatis, interspatiis costatis.

Long. 3 lin.

Hab.-New Guinea, Batchian.

Head smooth, impunctate; face slightly elevated between the insertion of the antennæ; carina linear; encarpæ transverse, contiguous. Thorax nearly twice as broad as long; sides straight and parallel; anterior angles oblique, thickened, hinder angles armed with a small tooth; above transversely convex, impunctate, impressed in front of the basal margin with a shallow, transverse groove, which is terminated on either side at some distance from the outer border by an indistinct longitudinal impression; lateral margin narrowly reflexed. Elytra rather broader than the thorax, parallel; above regularly punctate-striate; the interspaces thickened, costate; lateral margin narrowly dilated. 


\section{Genus Syphrea.}

Corpus late ovatum, valde convexum. Caput thorace immersum ; facie brevi, perpendiculari; oculis ovatis, intus leviter sinuatis; carinâ elevatâ, lineariformi; encarpis transversis, contiguis; antennis corporis dimidio multo longioribus, articulo secundo brevi, tertio illo dimidio longiori. Thorax transversus, lateribus anguste reflexo-marginatis, angulis anticis obtusis; convexus basi sulco transverso utrinque ad latus extenso impressus. Scutellum trigonatum. Elytra thorace latiora, valde convexa, confuse punctata. Pedes: coxis anticis prosterno fere æquialtis, femoribus posticis incrassatis; tibiis simplicibus, dorso non canaliculatis, singulis apice spinâ acutâ armatis; tarsis posticis ad tibiæ apicem insertis; unguiculis appendiculatis. Prosternum oblongum, postice vix ampliatum; acetabulis anticis apertis. Mesosternum transversum, apice rotundato-emarginato.

Strongly resembling Hermeophaga in form, but distinguished at once from that genus by the basal sulcation of the thorax extending entirely across the surface; from Sutrea and its allies it is separated by the above character as well as by the presence of a small acute spine at the apices of all the tibiæ; it may be known from Haltica by the very convex form, more especially of the thorax.

\section{Syphrea pretiosa.}

Late ovata, valde convexa, rufo-fulva, nitida, antennis, basi exceptis, pectore, abdomine, tibiis et tarsis anticis quatuor, pedibusque posticis totis, cæruleo-nigris; elytris metallico-cæruleis.

Long. 3 lin.

Hab.-Guatemala.

Vertex shining, impunctate; eyes black; two lower joints of antennæ obscure piceous. Thorax twice as broad as long; sides nearly straight and slightly diverging from the base to the middle, thence rounded and converging to the apex; hinder angles produced, acute; anterior angles thickened, moderately produced, obtuse ; above convex, minutely punctured, the puncturing only visible under a lens; at the base is a deep, transverse, sinuate groove, which extends entirely across the thorax; the surface between it and the basal margin at either end, rugose-strigose. Elytra broader than the thorax, very convex, transversely excavated below the humeral callus, distinctly punctured. 


\section{Genus Elytropachys, Motsch.}

Bull. Mosc. 1866, p. 419.

This genus, formed by Motschoulsky on some Ceylon insects formerly placed by him in Aphthona, is easily distinguished from most other genera of Halticina by the absence of a spine at the apex of the posterior tibia ; the hinder thighs are also much more slender than usual, and, in my opinion, it is doubtful whether its true position is in that group.

\section{Elytropachys quadripustulata.}

Ovata, valde convexa, nigra, nitida, tarsis (articulo basali excepto) antennisque fulvis, vertice rufo; elytris infia basin obsolete depressis, utrisque maculis duabus subrotundatis, unâ infra basin, alterâ pone medium positis, rufis.

Long. $3 \frac{1}{2}$ lin.

Hab.- - Singapore.

Head short, vertex smooth, marked with a transverse rufous patch; lower edge of clypeus, labrum and antennæ pale fulvous, the 3rd joint of the latter much longer than the 2nd; carina obsolete; encarpæ transverse, separated from each other by the apex of the clypeus. Thorax more than twice as broad as long; sides rounded, hinder angles distinct, anterior produced laterally into a small acute tooth; upper surface finely and remotely punctured. Scutellum smooth, trigonate. Elytra much broader than the thorax, broadly ovate, more coarsely punctured than the latter; on the outer disk of each, behind the middle, are two short longitudinal costæ. Hinder thighs slightly thickened.

\section{Elytropachys caruleipennis.}

Late ovata, valde convexa, nigra, nitida, fronte, scutello, pectoreque piceis; abdomine fulvo, elytris infira basin obsolete transversim depressis, metallico-cæruleis.

Long. $2 \frac{2}{3}$ lin.

Hab.-Cambodia.

Head smooth, clypeus trigonate, finely punctured, its lower edge, together with the labrum, obscure fulvous; carina obsolete; encarpæ transverse, separated by the apex of the clypeus; four lower joints of antenna obscure 
piceous, the $3 \mathrm{rd}$ joint one-half longer than the $2 \mathrm{nd}$. Thorax three times as broad as long; sides rounded, anterior angles produced, the apex obtuse, hinder angles acute; disk very finely and remotely punctured, the punctures only visible under a lens; anterior and posterior margins narrowly edged with piceous. Scutellum trigonate. Elytra faintly depressed below the basilar space, much more coarsely punctured than the thorax. 


\section{$2 \mathrm{BHL}$ Biodiversity Heritage Library}

Baly, J. S. 1876. "VI. Descriptions of new genera and species of Halticinæ." Transactions of the Entomological Society of London 24, 433-449. https://doi.org/10.1111/j.1365-2311.1876.tb01919.x.

View This Item Online: https://www.biodiversitylibrary.org/item/50987

DOI: https://doi.org/10.1111/j.1365-2311.1876.tb01919.x

Permalink: https://www.biodiversitylibrary.org/partpdf/30838

\section{Holding Institution}

Smithsonian Libraries

\section{Sponsored by}

Smithsonian

\section{Copyright \& Reuse}

Copyright Status: Public domain. The BHL considers that this work is no longer under copyright protection.

This document was created from content at the Biodiversity Heritage Library, the world's largest open access digital library for biodiversity literature and archives. Visit BHL at https://www.biodiversitylibrary.org. 